\title{
Performance Measurement of Energy Processes in Czech Production Plants
}

The part of research which is described in this article was focused on Performance Measurement of energy processes and approach especially of Czech production plants (defined below) to this area of interest. The main aim of the research was to check and describe the situation in the energy processes area of the Czech production plants, its managing and measuring. The aim of the article is to find and describe main impacts and actual approach of Czech industrial companies in energy processes performance measurement (energy prices and consumption analysis, actual level of performance measurement utilization in plant at all and directly in energy area, performance management (PM) methods utilization, KPI's used). For these results outputs from quantitative research were used. As was found, the energy processes, as supporting processes to core ones, in the production plants are not mapped, described and summarized in one methodical document to be able to increase the effectiveness of managing and performance measurement. The performance measurement methods are not used for energy processes. Key Performance Indicators (KPI's), which are included in the Performance Measurement System (PMS), are not stated, only the physical energy flow indicators are implemented in the local systems.

This was (and actually is) represented by the energy prices variation, respectively its increasing, absence of the clear statement of the coal usage and mining, the pressure to consumption reduction, reducing CO2 and the needs of fast reaction in various energy medium using.

Keywords: Energy Processes, Energy Management, Performance Measurement $(P M), \quad$ Key Performance Indicators, Performance Management (PM) Concepts.

\section{INTRODUCTION}

Performance Measurement sense was rapidly increased in the last years. Unfortunately, the energy area has not been touched by the benefits of process management yet. It is true, that some production plants declare that the process management has been implemented, but after the deep research it was only the predication.

Based on the reasons mentioned above, implementation of the Performance Management and Measurement and its benefits were very important for the next successful companies being. The energy area of each of the production plants was a key area for its operation and brings big costs with big savings possibilities. Management's decision making was influenced by a lot of external and internal impacts influencing the energy area.

The initial situation is described in the research result chapter. It contains the main reasons which lead authors to focus on the energy processes area. The main reasons came from Energy concept of European Union and Czech Republic comparison that has shown main

Received: June 2016, Accepted: May 2017

Correspondence to: doc. Ing. David Tuček, Ph.D.

Faculty of Management and Economics,

Tomas Bata University in Zlín, Czech Rep.

E-mail: tucek@fame.utb.cz

doi:10.5937/fmet1704670T

() Faculty of Mechanical Engineering, Belgrade. All rights reserved differences in the type of energy sources exploitation (the nuclear energy vs. the renewable energy sources such as wind power, solar power, water power and energy from the biomass), analysis of selected energy sources (prices and consumptions development) and from the questionnaire survey and case studies which was made in energy departments.

The article is aimed at energy Performance Measurement level in Czech industrial plants.

\section{LITERATURE REVIEW}

\subsection{Energy Processes, Energy Management}

The energetics is the branch, which is aimed at developing, forming, processing and transferring of energy.

Energy industries are described as the complex of supporting processes which ensure energy production operation, operation of administrative area, and next core processes.

Novak [1] wrote that energy process (as supporting process) is a complex of activities and its output is increasing of added value of energy materials which are going through it and ensuring of connected activities. The aim is to increase the added value for final customer and ensure the production.

Energy processes go through the whole company organization structure, whether it's from the inputs point 
of view (finance, material management, logistic) or outputs point of view (e.g. heat and light delivery for all of business units). The Figure 1 shows ensuring of energy process, resp. complete energy process for general energy medium.

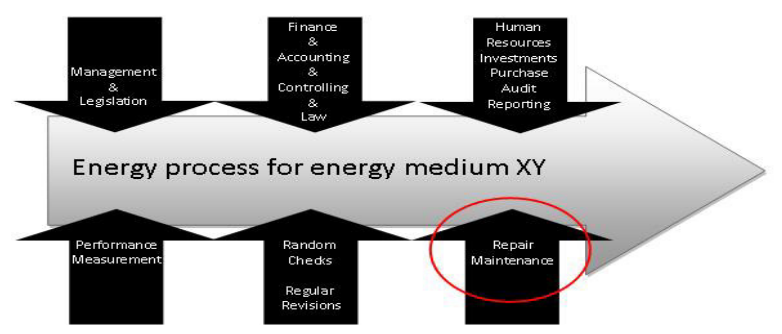

Figure 1. Ensuring of energy processes

Figure 2 shows sub process "Machines monitoring" made in ARIS software in detail.

The energy processes importance should be found or described with help of Balanced Scorecard's 4 perspectives as was described [2]:

- 1 st perspective (financial): energy processes contain one of the biggest shares of company costs and its optimalization may result in high cost savings. Dickens and Gould [3] showed a good approach with the idea of assigning of economic responsibility to managers to steer it as the corporate assets. Then they are under the top management pressure to make it more effectiveness.

- 2nd perspective (customer): the output is unique for customer and every variation has the big impact to the added value. The importance of energy processes rests in the machinery continuous operation on the part of customer, whose effort directly depends on energy deliveries.

- $\quad 3 r d$ perspective (innovation): new tendencies in renewable energy sources bring possibilities of process reengineering.

- 4th perspective (internal processes): as the energy processes are relatively easily measureable, it opens next reengineering possibilities. Because the energy processes run periodically, it may be simply automated. Next benefit can be found in outsourcing.

Energy management is defined by Capehart, Turner a Kennedy [4] as reasonable and efficient energy use for profit maximization (cost minimization) and competitiveness increasing.

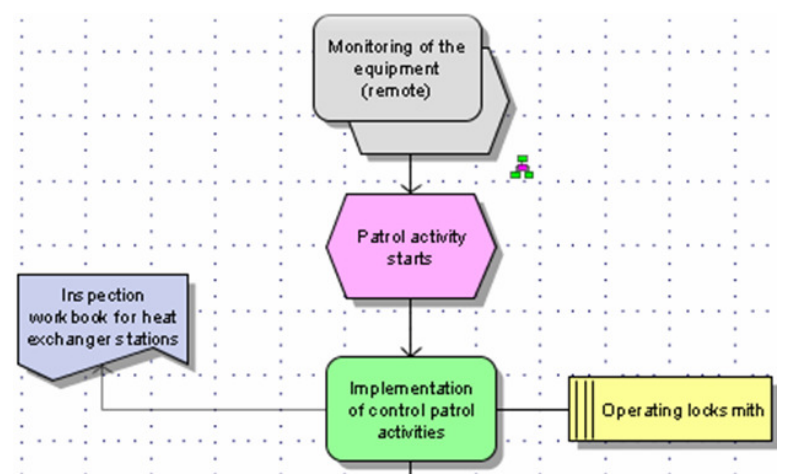

Figure 2. Process "Machine monitoring"
Colsys [5] describes Energy management as core control process ensuring the energy needs resp. Energy process working.

Main target of Energy management is ensuring of economic, reliable and environmentally thoughtful operating followed by covering all the energy needs.

\subsection{Energy Conception in CR and EU}

National Energy Conception was issued in 2007 and it is the strategy document which sets the energy strategic goals and priorities of Czech Republic with a forecast for the next 30 years [22].

One of the primary targets of European Union's Energy Strategy is creating of the conditions for market oriented economy with a help of internal energy power and natural gas market liberalisation [23].

If we look into Energy Conception of Czech Republic comparing with EU Energy Conception, we can find a lot of differences between it. Main differences are in area of green energy usage [24]. While EU is forecasting much more usage of wind and solar energy power, Czech Energy Conception is deal mainly with nuclear one. The actual situation in the energy sector is not stable due to the different goals of the European Union and Czech energy conceptions [25].

Based on these sources [23-25] we can state that: EU energy policy is mostly oriented to the increase of renewables consumption and Czech Republic policy don't want to refrain from nuclear and coal consumption.

Supporting processes including energy ones are surveyed though covering big optimalization potential. Energies are the quickest increasing type of costs even if the demand and the supply are balanced. Increasing prices, the differences between Czech and European Union's energy conceptions, these are the main reasons which should interest responsible managers [26]. In most part of industrial plants the concepts or methodical procedure "How to manage and measure energy processes" is missing. Key Performance Indicators are based only in costs or physical units. Nonfinancial complex indicators for the whole process are not used. Energy processes are not described and summarized to the overall plant process map. As well as the process dictionary is missing. Most of the activities in energy departments are based on historical basis and successful production measured by the failure's frequency. The functional managing approach is impeding to responsibility rules setting and effective information (data) flow. For example, wrong composition of repairs and revision plans, check errands missing plans and unreasonably applied recommendation standards are evoking duplicate activities working, wasting of energy and with regard this cost increasing. The main problem which is influencing the future progress and quality of process managing is missing concepts (rules) of energy process managing and measurement (which includes complex KPI's). It was tipical eg. In case study, that was solved in 2012 in company Barum Continental [19].

Only some plants declared usage of Process Management and any sophistic Performance measu- 
rement methods. This all will help to ensure the energy security in the production plants. Energy Process Management in Performance Measurement context is described only partially in the science literature. Available literature is aimed mostly to the energy sources flow and physical measurement. Bunse et. al [13] are confirming, that the gap between industrial plant needs and science literature exists in their research.

\subsection{The Performance Measurement}

When you can measure what you are speaking about and express it in numbers, you know something about it, said Lord Kelvin, W. T. [6]. Deming, W. E. [7] wrote that you cannot manage what you cannot measure.

Performance measures quantitatively tell us something important about our products, services, and the processes that produce them. These are tools to help us understand, manage, and improve what our organizations do. Department of Trade and Industry in the United Kingdom [8] defines that performance measures let us know: how well we are doing, if we are meeting our goals, if our customers are satisfied, if our processes are in statistical control, if and where improvements are necessary.

Neely, Gregory \& Platts [9] describe Business Performance Measurement System as "the set of metrics used to quantify both the efficiency and effectiveness of actions".

The key characteristics of BPM system should be studied in the paper of Franco-Santos et al. [10]. Fig. 3 bellow shows us how to proceed in measure performance.

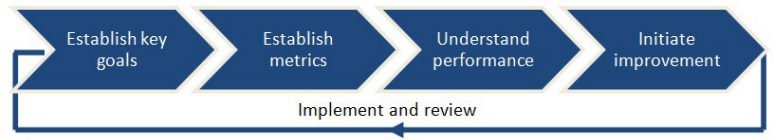

Figure 3. Performance Measurement process

In energy area there are a lot of metrics and measures defined in accordance to energy flow or to building heat cladding as declared in Torcellini, P., Pless, S., Griffith, B. and Judkoff, R. [11]. But, it's not defined for sub processes which ensure this energy flow (e.g. Full Time Equivalent, etc.).

Some appropriate measures should be learned and used from the US Department of Energy - special defense project from 1995 or from Czech Technical Standard released by Czech Office for Standards, Metrology and Testing [12].

Bunse et. al [13] writes in her research, that only few of relevant measures are used in energy area and standardized ones are completely missing there.

But it is important to be aware of the performance measurement as US Department of Energy recommends to keep in mind all the external and internal consequences in view of the first law of performance: If you try to be the best at everything, you'll be the best at nothing.

But it is important to be aware in performance measurement to keep in mind all the external and internal consequences in view of the first law of
performance:'If you try to be the best at everything, you'll be the best at nothing" [8].

Tucek, D., Tuckova, Z., and Zamecnik, R. [27] asked the respondents in their research, which concepts and methods (included to Performance Measurement system) are used in production plants.

There were mentioned Activity Based Costing (ABC), Balanced Scorecard (BSC), Benchmarking, and European Foundation for Quality Management (EFQM), and other. Our Research is using the same methods and concepts and is looking for the consequences in all the plant and individually in the energy area.

\section{PROCESS APPROACH TO THE ENERGY PRO- CESSES MANAGEMENT AND ITS VALUATION IN CZECH PRODUCTION PLANTS}

\subsection{The goal of the quantitative research}

The aim of article is to find and describe main impacts and actual approach of the Czech industrial companies in energy processes performance measurement (energy prices and consumption analysis, actual level of performance measurement utilization in plant at all and directly in energy area, PM methods utilization, KPI's used). For this purposes, outcomes from quantitative research were used.

\subsection{Research methodology of quantitative and qualitative research}

The research results are listed in summary fashion for all of the researched Czech production plants, which were 59 at all (it was received 78 questionnaires but 19 incomplete). Parent population was 4.830 companies (base criteria: min. 50 employees, CZ-NACE, category item 10-33 production activities). The selective group was 757 companies (criteria: energy departments inside the company and energy management availability). Questions were selected as semi-closed to be able to answer respondents own opinion by Gill and Johnson [14] methodology. Questionnaires return was 8.7\%. It may seem not much, but Eschenbach [15] presents the return from $7 \%$ to $47 \%$ in controlling researches which are near to energy area specification. These researches were much more general.

Case studies were made in 12 big Czech industrial plants were used as the next data source (qualitative research) for the whole research. Case studies include direct interview of energy managers. This questionnaire main companies describes the level of process management implementation, KPIs indicators and performance measurement methods.

\subsection{Research results}

At first the EU and CZ energy concepts were analyzed. Key indicators of EU energy policy contain Agreement between member states and the secondary policy which is concerned with competition and state support. The Policy is promoted with help of the Regulations. One of the primary targets of the EU energy strategy is creating of market conditions for electric and natural gas. This is 
followed by the Czech Republic too. But if we look at energy concepts of EU and the Czech Republic we can find fundamental differences in the future usage of energy sources. While EU is oriented to renewable energy sourcing usage, Czech Republic is oriented to nuclear energy source. This is first impact which effects thinking of energy managers.

We can find next impact in energy sources prices and its consumption. The mostly used energy sources are: electric power, heat energy (hot steam, coal), gas and water. Based on the case studies results, companies, due to cost savings, very often risk during energy sources purchasing by the gradual purchase. But, for example, if prices grow in the long term (and company didn't fix a contract with the fix prices) it could lose. Czech companies use this approach because the prices in the Czech Republic growth rapidly.

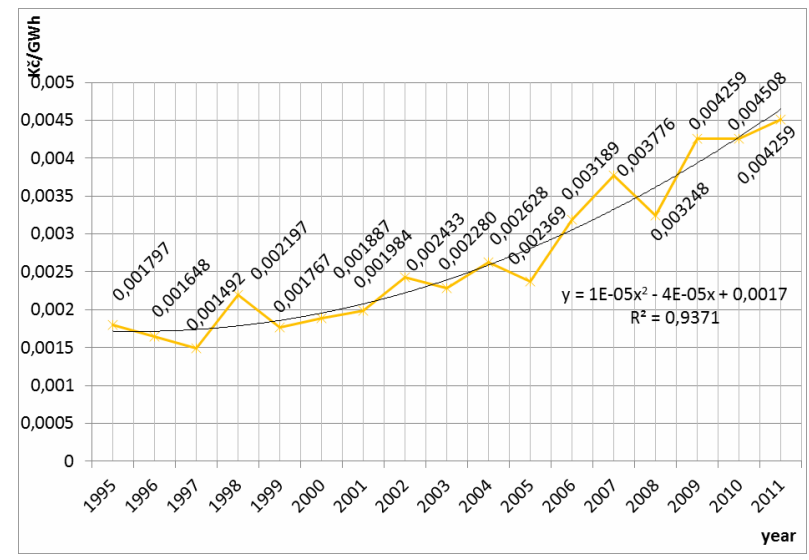

Figure 4. Development of electro average prices in Czech energy market [16], [17]

Consequently, the consumptions and prices development were compared with the results shown in Fig. 4. (in Czech energy market - in general) and in Fig. 5 (in Czech industry). There was strong linear correlation between prices and the consumptions $(0,81)$. The analysis returned more or less linear growth of both indicators.

The heat energy analysis showed the similar situation, but here we can see (Fig. 6) the impact of the production plants to take an action in order to reduce the consumption by the heat cladding.

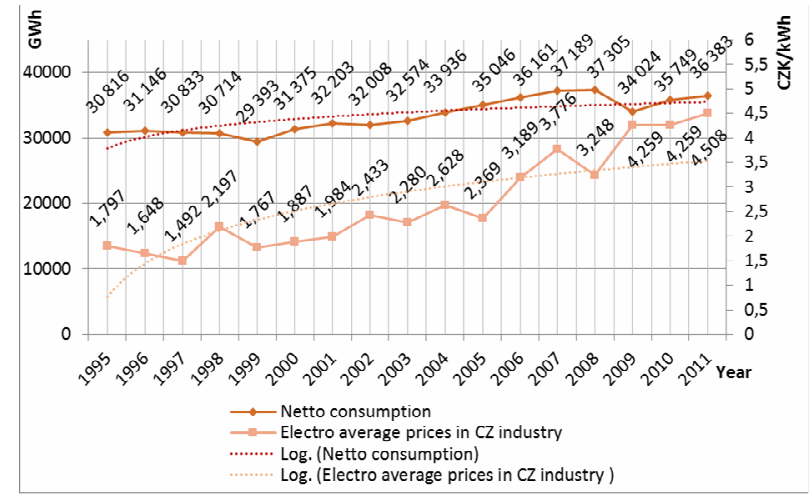

Figure 5. Development of electro average prices and consumptions in Czech industry

There could be expected next growth of energy sources for long time as Energy Regulation Office [18] shown in its analysis.

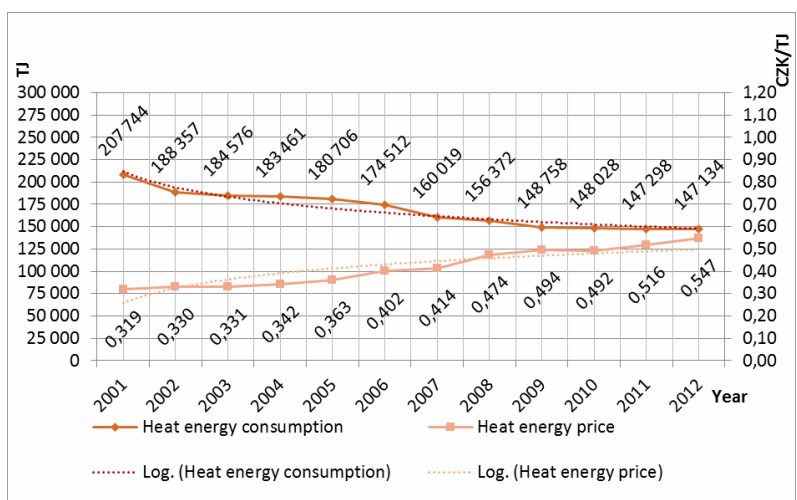

Figure 6. Development of heat energy prices and consumptions in Czech energy market

Tab. 1 shows Energy technician activities before and reducing after project. If we will calculate only the employee controlling costs 500.000 ,- CZK per year (incl. salary, taxes, staff's equipment) we can achieve 250.000,- CZK cost savings per year. This is accelerated with the other functions and reorganization of the department (reducing of redundant activities, describing and setting of checks, using process description for entry learning of new employee, effective reporting and planning sources, material and people, etc.). This approach may balance price increasing of energy sources and make the plants to be prepared for fluctuations.

Table 1. Technician function activity analysis - savings

\begin{tabular}{|c|c|c|c|c|}
\hline \multirow{2}{*}{ Activity } & \multicolumn{2}{|c|}{ Before project } & \multicolumn{2}{c|}{ After project } \\
\cline { 2 - 5 } & hrs./year & FTE & hrs./year & FTE \\
\hline $\begin{array}{c}\text { Internal repairs, } \\
\text { specifications and } \\
\text { material ensuring }\end{array}$ & 846 & $28 \%$ & 282 & $16 \%$ \\
\hline $\begin{array}{c}\text { Machine } \\
\text { maintenance }\end{array}$ & 546 & $18 \%$ & 156 & $9 \%$ \\
\hline $\begin{array}{c}\text { External repairs } \\
\text { (tender } \\
\text { procedures) }\end{array}$ & 282 & $9 \%$ & 282 & $16 \%$ \\
\hline $\begin{array}{c}\text { Small external } \\
\text { repairs - } \\
\text { organizing }\end{array}$ & 235 & $8 \%$ & 235 & $13 \%$ \\
\hline Reporting & 232 & $8 \%$ & 118 & $7 \%$ \\
\hline $\begin{array}{c}\text { Investment } \\
\text { department } \\
\text { cooperation }\end{array}$ & 141 & $5 \%$ & 141 & $8 \%$ \\
\hline Planning & 184 & $6 \%$ & 13 & $1 \%$ \\
\hline Meetings & 188 & $6 \%$ & 188 & $11 \%$ \\
\hline Improvements & 24 & $1 \%$ & 24 & $1 \%$ \\
\hline Others & 324 & $11 \%$ & 324 & $18 \%$ \\
\hline Total & 3001 & $100 \%$ & 1763 & $100 \%$ \\
\hline
\end{tabular}

Based on the analysis mentioned above, the main impacts were set up to manage the energy processes and future decision making. It was helpful for research questionnaire formation too.

1st EU and Czech energy concepts differences have a big impact on company's energy planning at strategic level to hold the competition advantages.

2nd The analysis of the energy sources prices and its consumption showed the growth. This evokes requirement of manager's approach to change energy processes managing. The automation and simulation of virtual plants 3D models should be used. 
3rd The analysis of heat energy showed requirement of additional investments to heat cladding of the buildings and machinery complement with regulation technology.

\subsection{Research results of quantitative research}

This research results are only a part from quantitative research. This part of research had shown the significant differences between usage of the PM in business and energy processes areas.

The respondents were asked if theirs plants are interested in Performance Measurement of business processes at first.

$41 ; 69,5 \%$ answer yes and the rest $(18 ; 30,5 \%)$ no.

For the energy processes area is the situation opposite ( $2 ; 42,4 \%$ answered yes, $34 ; 57,6 \%$ said no). See Figure 7.

It shows that companies are aimed at business processes area at all, but not so deeply interested in PM of the energy processes.

\section{Are you interested in performance measurement of business and especially energy processes?}

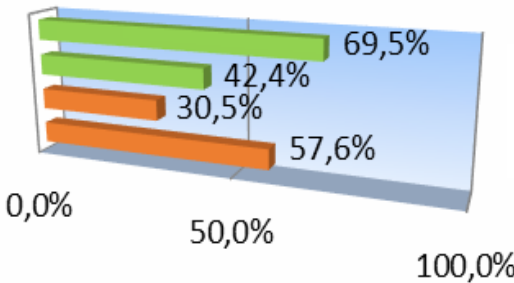

Yes $(69,5 \%)$

$\operatorname{No}(30,5 \%)$

\section{Energy processes NO $\quad$ Business processes NO \\ $\square$ Energy processes YES $\square$ Business processes YES}

\section{Figure 7. PM in business and energy processes areas}

The xext question is if the responsibility for energy processes measuring and its goals is defined (see Fig. 8).

The respondents answered in 25\%; 15 that yes, but without the relation to employee's rewarding, 33,9\%; 20 that yes with the relation to employee's rewarding and finally $40,7 \%$ that no responsibility is defined. It showed that even if the processes could be measured, nobody was responsible for it or was responsible but without the motivation, so there was not any impulse to increase the effectiveness by the employees in the energy departments.

Gleich [20] compared Performance Measurement concepts (see Tab. 2 bellow). He compared and evaluated 14 concepts of Performance Measurement based on 11 decisive criteria. Each of these criteria characterizes important part or the functionality of Performance Measurement concept. All the criteria should be evaluated in six concepts. All these concepts are widely described and used (e.g. Balanced Scorecard or Performance Pyramid), or its functionality is based on maths calculations (Data Envelopment Analysis).

The best concepts which fulfilled most of criteria are: Balanced Scorecard, Hewlett-Packard company concept, Performance Pyramid and Quantum Performance Measurement.

\section{Is the responsibility defined for energy processes measuring and it's goals?}

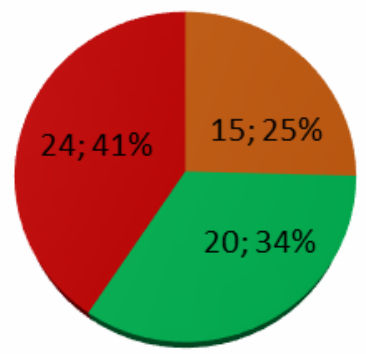

a, YES, without the relation to employee's rewarding.

a, YES, with the relation to employee's rewarding.

- c, NO

Figure 8. Responsibility for energy processes measuring

We can see that Balanced Scorecard concept occurs in all the studies as one of the most used and the most suitable concept (for the whole plant and energy area too).

Table 2. Performance Measurement concepts comparison

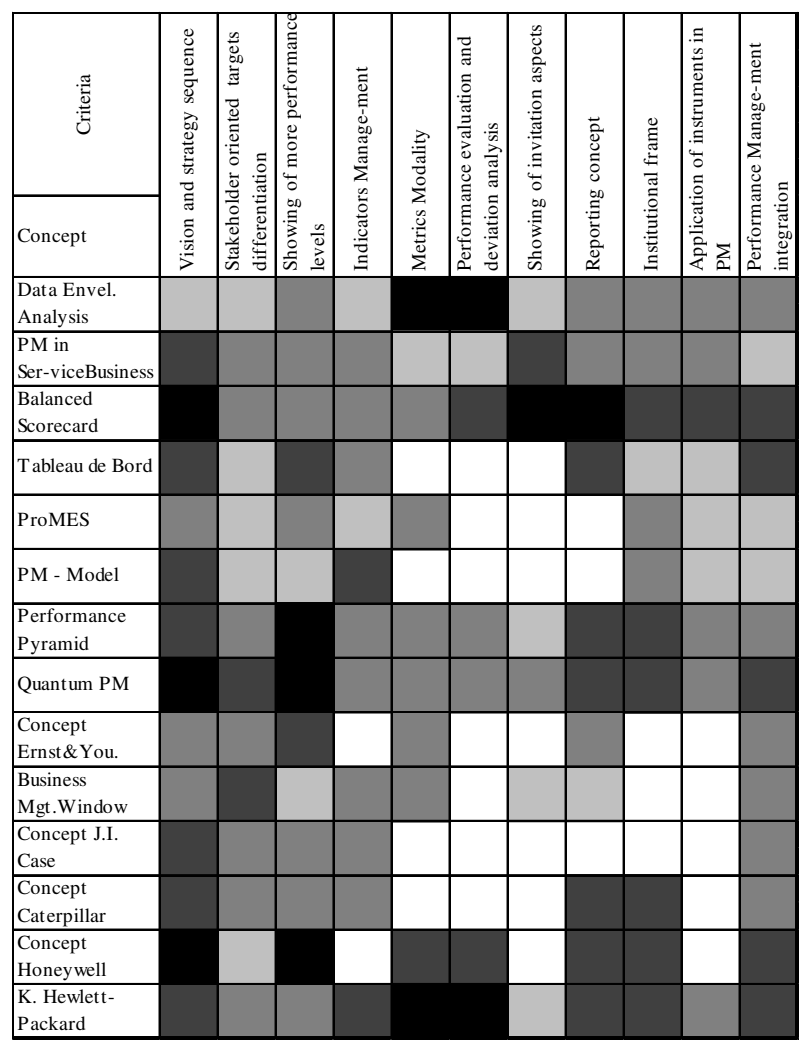

\begin{tabular}{|c|l|}
\hline Black & Widely covered by the concept \\
\hline Grey 75\% & Covered by the concept \\
\hline Grey 50\% & $\begin{array}{l}\text { Covered minimally / only conditionally by } \\
\text { the concept }\end{array}$ \\
\hline Grey 25\% & Not covered by the concept \\
\hline White & $\begin{array}{l}\text { Impossible to evaluate for missing } \\
\text { information }\end{array}$ \\
\hline
\end{tabular}

Tuček a Zámečník [21] asked respondents in their research, which concepts (included to Performance 
Measurement System) are used in the industrial plants. Respondents introduced Activity Based Costing (ABC), Balanced Scorecard (BSC), Benchmarking, and European Foundation for Quality Management (EFQM), Performance Pyramid, Six Sigma and Value Based Management (VBM) concepts.

Authors used these concepts as the base to find out if the industrial plants use it in the energy area, too (as mentioned above). The research showed that for the energy departments in industrial plants, there doesn't exist any universal method or concept. As was found in the research, companies use a complex of the concepts, or their own method which come from the best concepts benefits but not in the energy area. $24 \%$ of industrial plants don't use any concept or its combination included in Performance Measurement system in the company. $76 \%$ of companies use concepts mentioned in Table 3.

Table 3 Concepts rank use in the Czech plants

\begin{tabular}{|c|l|c|}
\hline No. & \multicolumn{1}{|c|}{ Concept } & Share \\
\hline 1 & Benchmarking & $48 \%$ \\
\hline 2 & BSC (Balanced Scorecard) & $35 \%$ \\
\hline 3 & ABC (Activity Base Costing) & $24 \%$ \\
\hline 4 & $6 \delta$ (Six Sigma) & $22 \%$ \\
\hline 5 & $\begin{array}{l}\text { EFQM (European Foundation for Quality } \\
\text { Management) }\end{array}$ & $13 \%$ \\
\hline 6 & VBM (Value Based Management) & $9 \%$ \\
\hline 7 & DEA (Data Envelope Analysis) & $7 \%$ \\
\hline
\end{tabular}

For energy area the respondents recommended concepts mentioned in the table below.

Table 4 Concepts rank in energy area

\begin{tabular}{|c|l|c|}
\hline No. & \multicolumn{1}{|c|}{ Concept } & Share \\
\hline 1 & Benchmarking & $44 \%$ \\
\hline 2 & BSC (Balanced Scorecard) & $39 \%$ \\
\hline 3 & ABC (Activity Base Costing) & $27 \%$ \\
\hline 4 & $6 \delta$ (Six Sigma) & $24 \%$ \\
\hline 5 & $\begin{array}{l}\text { EFQM (European Foundation for Quality } \\
\text { Management) }\end{array}$ & $15 \%$ \\
\hline 6 & VBM (Value Based Management) & $10 \%$ \\
\hline 7 & DEA (Data Envelope Analysis) & $5 \%$ \\
\hline
\end{tabular}

The research result showed that the first three most preferred concepts (for whole company as well as in energy area) are Benchmarking, Balanced Scorecard and Activity Based Costing.

\subsection{KPI's and performance measurement methods}

KPI used in energy departments in Czech production plants covers only the general energy flow and doesn't reflect other processes which ensure this flow. In addition $50 \%$ of production plants do not deal with performance measurement with help of Key Performance Indicators.

As was expected, companies use mostly KPI's aimed at energy flow evaluation (costs and time 100\%, physical measures 63\%).

The respondents were asked which KPI's they prefer in the case of its implementation from all processes point of view, especially the energy processes point of view.

As the results showed the most mentioned indicators for both areas are the costs, growth, finance and the quality (see Figure 9, 10 below).
Choose 4 main KPI's, which you prefer from the whole company point of view.

$0 \% \quad 20 \% \quad 40 \% \quad 60 \% 80 \% 100 \%$

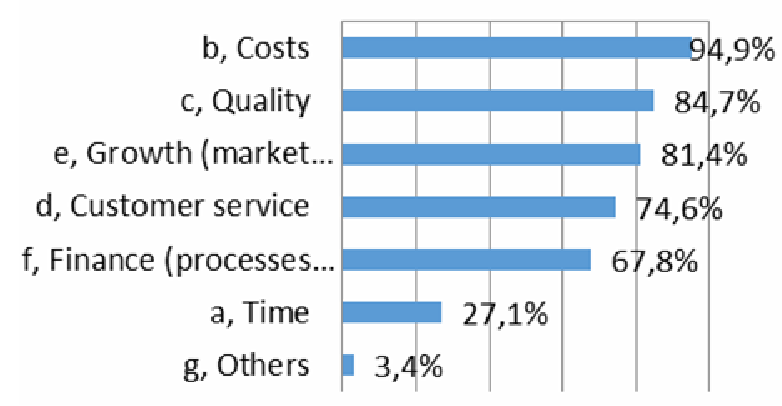

Figure 9. KPI's plants area

Choose 4 main KPI's, which you prefer from the energy area point of view.

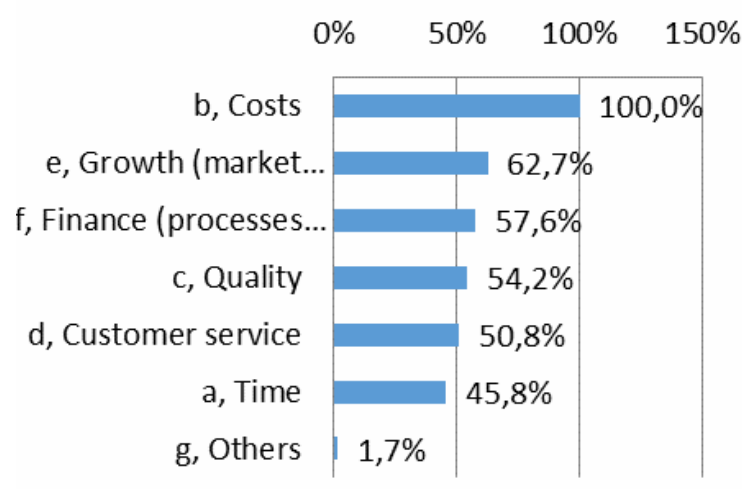

Figure $10 \mathrm{KPI}$ 's energy area proposal

\section{CONCLUSION}

Actually, most of the Czech production plants are not prepared for flexible reaction to $\mathrm{EU}$ and $\mathrm{CZ}$ energy concept changes and differences with a view to energy flow ensuring.

Within the literary research it was found that not many authors deal with energy processes with a view to ensuring of energy flow in the production plants. The best literature sources come from the United States and United Kingdom, respectively, by the authors who made projects for the US Government and for UK Department of Trade and Industry. But we can find and use the sources intended for repair and maintenance area (mostly Key Performance Indicators questions). The problem of the energy flow processes in general is much more described.

Based on the analysis mentioned in chapter 3.4., main impacts were set up to the Performance management and future decision making and Performance Measurement concepts comparison upon our research in Table 2.

Next findings showed that there exist big differences in performance measurement usage in the industrial companies at all and directly in the energy area. The questionnaire research and case studies demonstrated the complete research missing of energy process maps, describing and existing of complex measures including energy sub processes. The process approach is missing even if implementation of the BPM is mentioned. We 
can find physical measures and methods to increase energy efficiency and reduce the energy costs.

This kind of project is e.g. finding the energy efficiency model in context energy consumption in the project of authors: Lerher et. al. [28].

However, it is not sufficient. Key Performance Indicators, which are used in the Performance Measurement system, are not stated. The measures are set for alone energy medium flow only, not for the whole process in its complexity.

Regarding Performance Measurement systems and methods usage, KPI's setting and responsibilities, the research had shown big space for improving in the energy processes area.

Based on the results and conclusions, there is a lot of improvement space. Also, the Process Management brings the benefits which are not used in energy departments. For the plant economists is very hard to estimate and plan the costs of energy processes as well as plant or evaluate the investments. Due to this reasons and reasons mentioned above (prices, consumption) it is very important to define the processes, make the process map, set up rules following laws and internal policies covered to the complete methodical manual. This will help not only Energy managers are to be prepared for the unexpected changes and, in addition, for position training of new staff. Appropriate Process Management in energy area and comprehensive performance measurement of energy processes will bring competitive advantage to the production plants. The main benefits which could be useful for industrial plants are, beside others, flexible managing of the energy departments, headcount decreasing, duplicate activities reducing, faster training of new staffs and of course costs saving.

\section{REFERENCES}

[1] Novák, Z., Energy processes management and valuation in production companies using Key Per-formance Indicators according to sampled methods from Performance Measurement system, Thesis of dissertation, Tomas Bata University in Zlín, pp. 11, 2011.

[2] Kaplan, R. S., Norton, D. P., Balanced Scorecard, $1^{\text {st }}$ issue, Prague: Management Press, pp. 267, 2000.

[3] Dickens Ch., Gould, K., Process as an Asset, BP trends,http://www.bptrends.com/ publicationfiles /0708ARTProcess\%20as\%20an\%20AssetDicken\% 20and\%20Gould - final.doc.pdf, 2010.

[4] Capehart, B. L., Turner, W. C., Kennedy, W. J., Guide to Energy Management. 6th issue. New York: Fairmont Press, pp. 625, 2008.

[5] Colsys Automatik, Co je energetický management? [online], Kladno. [cit. 2010-02-10]. Available form http://www.indetcon.cz/co-je-energetickymanagement, February 2010.

[6] Lord Kelvin, W. T., Lecture to the Institution of CivilEngineers,http://www.todayinsci.com/K/Kelvin_L ord/Kelvin_Lord.htm 21883 .

[7] Deming, W. E., The New Economics For Industry, Government \& Education. Cambridge: Massachusetts Institute of Technology Center for Advanced Engineering Study, $2^{\text {nd }}$ edition, 1993.
[8] Department of Trade and Industry, United Kingdom, How to Measure Performance - A Handbook of Techniques and Tools, www.dti. gov.uk/quality/performance, pp. 7, 1995.

[9] Neely, A. D., Gregory, M. J., Platts, K., Performance Measurement System Design: a Literature Review and Research Agenda“, International Journal of Operations \& Production Management,Vol. 15, No. 4, pp. 80-116, 1997.

[10] Franco-Santos, Met al.: Towards a definition of a business performance measurement system, International Journal of Operations and Production Management, Vol. 27(8), pp. 784-801, 1995.

[11] Torcellini, P., Pless, S., Griffith, B., Judkoff, R., Evaluation of the Energy Performance and Design Process of the Thermal Test Facility at the National Renewable Energy Laboratory, Operated for the U.S. Department of Energy, http://www.osti.gov /bridge, pp. 12-123, 2005.

[12] Czech Office for Standards, Metrology and Testing, ČSN EN 15241 Maintenance - Maintenance Key Performance Indicators, pp. 23, 2010.

[13]Bunse K. et al., Integrating energy efficiency performance in production management - gap analysis between industrial Leeds and scientific literature. Journal of Cleaner Production [online]. pp. 667-669, vol. 19, 2011.

[14] Gill, J., Johnson, J. P., Research Methods Managers. Publisher: Paul Chapman Publishing Ltd., London, pp. 170, 1991.

[15]Eschenbach, R., Controlling Prague: Aspi publisher, pp. 816, 2004.

[16]Czech Statistical Office, Public database-energy industries, http://www.czso.cz/csu/produkty.nsf /podskupina?openform\&:2010-E81, 2011.

[17] International Energy Agency, IEA Guide to Reporting Energy RD\&D Budget / Expenditure Statistics, http://www.iea.org/stats/rd.asp

[18]Energy Regulation Office, Gas deliveries and consumption prognosis 2012-2021, http://www.eru. cz/user_data/files/plyn/40_statistika/prognoza/Dese tileta\%20prognoza.pdf, 2012.

[19] Tučková, Z. et al.: Electric energy department analysis, TBU and Barum Continental common project presentation, Otrokovice, 2012.

[20] Gleich, R., Performance Measurement als Controllingaufgabe. In: Controlling Fortschritte Verlag Vahlen, München, pp. 49-75, 2002.

[21] Tuček, D., Zámečník, R., Business process Management and Performance Measurement in practical, Publisher: Technical University Zvolen, pp. 206, 2007.

[22] Ministry of Industry and Trade of CR, "National Energy Efficiency Action Plan of the Czech Republic", [online], April 2007, [cit. 2017-05-17]. Available form https://www.mpo.cz/assets/ dokumenty 155405/63436/653021/priloha003.pdf , 2007.

[23] Ministry of Industry and Trade of CR, "State energetic conception", [online], February 2010. [cit. 
2017-05-17]. Available form http://www.mpo.cz /dokument5903.html, 2010.

[24] Ministry of Industry and Trade of CR, "National Energy Efficiency Action Plan of the Czech Republic", [online], August 2011, [cit. 2017-05-17]. Available form https://www.mpo.cz/assets/dokumenty 155405/63436/653022/priloha002.pdf, 2011.

[25] Ministry of Industry and Trade of CR, "National Energy Efficiency Action Plan of the Czech Republic", [online], October 2014, [cit. 2017-05-17]. Available form https://www.mpo.cz/assets /dokumenty /55405/63436/653023/priloha001.pdf, 2014.

[26] Ministry of Industry and Trade of CR, "National Energy Efficiency Action Plan of the Czech Republic", [online], February 2016 [cit. 2017-05-17]. Available form https://www.mpo.cz/assets/en /energy /energy-efficiency/strategic-documents/2016/12/CZ_ neeap_update_2-2016_en_3.pdf, 2016.

[27] Tucek, D. et al. "Business Process Management with Software Support" In Proceedings of the 13th International Business Information Management Association Conference: Knowledge Management and Innovation in Advancing Economies Analyses \& Solutions. Norristown: IBIMA., pp. 1060-1073, 2009.

[28]Lerher, T., Edl, M., Rosi, B. Energy efficiency model for the mini-load automated storage and retrieval systems. International Journal of Advanced Manufacturing Technology, 2013, č. 2013, s. 1-19.

\section{МЕРЕЊЕ ПЕРФОРМАНСИ ЕНЕРГЕТСКИХ ПРОЦЕСА У ЧЕШКИМ КОМПАНИЈАМА}

\section{Д. Тучек, 3. Тучкова, Д. Јелинкова}

Део истраживања приказан у овом раду бави се мерењем перформанси енергетских процеса и приступа у чешким производним компанијама (наведеним у даљем тексту). Циљ истраживања је био да се провери и опише ситуација у области енергетских процеса у чешким производним компанијама. Аутори су утврдили и описали главне утицаје и актуелан приступ индустријских компанија мерењу перформанси енергетских процеса (цене енергената и анализа потрошње, актуелан ниво коришћења мерења перформанси у компанији уопште и директно у области енергетике, примена метода управљања перформансом, коришћени кључни показатељи перформансе). Резултати су добијени из аутпута квантитативних истраживања.

Утврђено је да енергетски процеси, као главна подршка базним процесима, нису мапирани, описани, нити резимирани у једном документу како би се повећала ефикасност управљања и мерење перформанси. Методе мерења нису коришћене за енергетске процесе. Кључни показатељи перформанси, који су обухваћени системом мерења перформанси, нису наведени, осим што су показатељи протока физичке енергије примењени у локалним системима. Ово је приказано варирањем цена енергената, односно њиховим повећањем, ненавођењем података о коришћењу угља и рударству, притиску да се смањи потрошња, смањи емисија $\mathrm{CO}_{2}$ и потребе да се брзо реагује код потрошње различитих енергената. 